\title{
РОЛЬ БІЛКІВ ГОСТРОЇ ФАЗИ ПРИ СТРЕСОВОМУ НЕТРИМАННІ СЕЧІ
}

\author{
Литвинець Людмила Ярославівна, д.мед.н., професор, Івано-Франківський національний \\ медичний університет, м. Івано-Франківськ, Украйна, \\ Литвинець Владислава Свгенівна, асистент, Івано-Франківський національний медичний \\ університет, м. Івано-Франківськ, Україна, \\ Горовий Віктор Іванович, к.м.н., доцент, Вінницький національний медичний університет \\ ім. М.І. Пирогова, м. Вінниия, Україна, \\ Литвинець-Голутяк Уляна Свгенівна, к.м.н, дочент, Івано-Франківський національний \\ медичний університет, м. Івано-Франківськ, Украӥна
}

\section{DOI: https://doi.org/10.31435/rsglobal_conf/30122020/7348}

Abstract. Стресове нетримання сечі - одне з найбільш поширених захворювань серед жіночого населення, вкрай негативно позначається на якості життя пацієнток. Серед факторів, які зумовлюють зміни при запальному прочесі, велике значення мають так звані білки гострої фази. Беручи до уваги загальну біологічну функиію СРБ, слід вважати закономірним знаходження иьього білка безпосередньо в "осередках ураження". Метою нашої роботи стало дослідження вмісту СРБ у сечі та крові пацієнтів зі стресовим нетриманням сечі. Нами 45 хворих на СНС віком від 35 до 75 рр. Групу контролю склали 25 здорових жінок аналогічного віку. У сироватиі крові хворих на СНС при поступленні реєстрували підвищення рівня СРБ, практично у всіх хворих він досягав «гострозапального» діапазону $і$ становив в середньому $15,64 \pm 3,56$ мг/л $(p<0,001)$. Одночасне визначення СРБ у сечі хворих на СНС виявило концентрації біомаркера, що в 4-5 разів перевищували показники в крові $і$ становили в

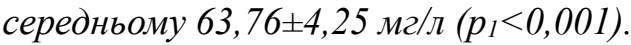

Keywords: стресове нетримання сечі, гостро фазові білки.

Вступ. Протягом останнього десятиріччя спостерігається істотне зростання частоти стресового нетримання сечі у жінок (CHC). 3 одного боку, це пов'язано 3 поліпшенням діагностики, а з іншого - зі зростанням вірулентності мікроорганізмів унаслідок набутої ними резистентності до антибіотиків та інших антимікробних препаратів $[1,5]$.

Згідно 3 рекомендаціями комітету по стандартизації термінології Міжнародного товариства 3 вивчення утримання сечі (International Continence Society - ICS) під нетриманням сечі (НC) розуміють будь-яке мимовільне (неконтрольоване вольовими зусиллями та не зв'язане 3 бажанням пацієнта) виділення сечі $[5,7]$. Кожна четверта жінка після 30 років відмічає симптоми нетриманням сечі, у тому числі і в Україні. Нетримання сечі $є$ тяжким стражданням для жінки, пригнічує іiї психіку, знижує працездатність, не дає можливості перебувати в громадських місцях, а також є однією 3 причин розлучень. Близько $25 \%$ гігієнічних прокладок використовуються жінками при нетриманні сечі $[5,7,8]$. Недостатня інформованість населення стосовно нетримання сечі у жінок, а також знань урологів, гінекологів та лікарів суміжних спеціальностей про сучасні методи діагностики та лікування приводять до того, що лише одна із $10-25$ жінок звертається за допомогою до лікаря і тільки 10-30\% отримують кваліфіковану допомогу. Результати наших досліджень показали, що близько $60 \%$ жінок із нетриманням сечі звертаються до лікаря в строки від 1 до 5 років від початку захворювання, ще 17\% - в строки від 6 до 10 років, $8 \%$ - через 10 років і лише $15 \%$ - на протязі першого року захворювання [7, 8]. Мимовільне виділення сечі через уретру відносять до уретрального НС, якщо ж виділення сечі відбувається не через уретру, тоді говорять про екстрауретральне НС (зустрічається при екстрофії сечового міхура, міхурово - піхвових норицях, ектопії вічка сечоводу подвоєної нирки в присінок піхви та ін.). ICS виділяе наступні види нетримання сечі у жінок: стресове (нетримання сечі при напруженні), імперативне (ургентне), змішане, енурез (нічне нетримання сечі), постійне та інші види нетримання сечі, які можуть бути ситуаційними (під час статевих зносин, сміху, після сечовипускання). J.G. Blaivas та ін. добавляють до вищевказаних видів НC ще 3 види: несвідоме (рефлекторне), яке зустрічається при нейрогенному сечовому міхурі; нетримання сечі від перенаповнення сечового міхура (парадоксальне НС) та підтікання сечі після закінчення акту сечовипускання (зустрічається при дивертикулі уретри) $[8,9]$. 
Серед факторів, які зумовлюють зміни при запальному процесі, велике значення мають так звані білки гострої фази. Дослідження С-реактивного білка (СРБ) в плазмі/сироватці крові широко застосовується в клінічній практиці в якості раннього і чутливого індикатора запальної відповіді. СРБ відносять до "головних" білків гострої фази: його концентрація при бактеріальній інфекції, пошкодженнях тканин, некрозі - стрімко ( в перші 6-8 год.) і дуже значно ( в 20-100, а іноді в 1000 разів) зростає, тоді як у здорової людини рівень СРБ в плазмі крові знаходиться в слідових кількостях. Беручи до уваги загальну біологічну функцію СРБ, слід вважати закономірним знаходження цього білка безпосередньо в "осередках ураження" $[1,2]$. Так, при імуногістохімічних дослідженнях матеріалів аутопсій хворих з гострим інфарктом міокарда СРБ поряд 3 активованими компонентами комплемента було знайдено в інфарктній зоні міокарда, стінках коронарних судин, в атеросклеротичних бляшках. За даними К. Yasojima, рівень СРБ в атеромах в 7 разів перевищував його рівень в печінці. Високий рівень СРБ було також зареєстровано в тканинах абдомінальної аневризми аорти. Крім того, вчені техаського університету W. Jabs, J. Willerson доказали можливість екстрапечінкового синтезу СРБ лімфоцитами, макрофагами та епітеліальними клітинами канальців нирок in vitro $[3,4,6]$.

Ймовірно, синтезу СРБ у вогнищах ураження сприяе високий рівень прозапальних цитокінів. Основними індукторами виділення СРБ вважаються IЛ-1, ІЛ-6, ФНП- $\alpha$, підвищення даних цитокінів у крові викликає синтез СРБ гепатоцитами печінки. Проте, на сьогодні немає даних про вплив цитокінів, які вважаються основними індукторами виділення СРБ на концентрацію даного біомаркера в сечі і до кінця не з'ясована їх роль в хронізації запального процесу.

Мета роботи. Дослідження вмісту СРБ у сечі та крові пацієнтів зі стресовим нетриманням сечі.

Матеріал та методи дослідження. В основу дослідження покладено результати комплексного обстеження 45 хворих на СНC, які перебували на амбулаторному (поліклініка) та стаціонарному лікуванні в урологічному відділенні Івано-Франківської ОКЛ віком від 35 до 75 pp. Тривалість захворювання пацієнтів була від 2 до 26 років, в середньому $-12,6 \pm 3,17$ років. У більшості пацієнтів (37,5\%) СНС тривав 5-10 років. Тривалість анамнезу СНС менше 5 років зустрічалась у 27,5 \% хворих, а більше 10 років - у 35,0 \% хворих. Групу контролю склали 25 здорових жінок аналогічного віку. Діагностику СНС здійснювали згідно наказу МОЗ України "Про затвердження клінічних протоколів надання медичної допомоги за спеціальністю "Урологія", який на даний час є загальноприйнятим в Україні. Діагноз СНС виставляли на основі клінічних, лабораторних та інструментальних досліджень.

Визначення рівня С-реактивного білку в біологічних рідинах організму. СРБ виявляється в сироватці при різних запальних та некротичних процесах і $є$ показником активності перебігу захворювання. Встановлено, що рівень СРБ в плазмі (сироватці) крові підвищується протягом 2448 годин після гострого пошкодження тканин і у цей період досягає максимальної концентрації, яка може в 100-1000 разів перевищувати його базальний рівень. Рівень СРБ в сироватці відображає інтенсивність запального процесу, і контроль за ним важливий для моніторингу захворювань. У сироватці здорових людей СРБ визначається в слідових концентраціях. Визначення СРБ проводилося в двох варіантах: у плазмі (сироватці) крові та в сечі. Дослідження СРБ проводилося за допомогою діагностикуму латексного для виявлення С-реактивного білку "СРБ - латекс-тест" ТОВ НВЛ "Гранум", м. Харків. Державний реєстраційний номер №1248/2002. Метод грунтується на виявленні білка гострої фази — C-реактивного протеїну, який вступає в реакцію аглютинації з антитілами проти С-реактивного білка, що адсорбовані на нейтральних частинках латексу. Оцінку проводять згідно з останнім титром сироватки, який дав позитивний результат. Для визначення кількості СРБ в мг/л у пробі, необхідно найбільше розведення сироватки, що дало видиму аглютинацію, помножити на 6 мг/л.

Результати і обговорення. Діагностична цінність СРБ може бути пояснена тривалим часом напіврозпаду, відсутністю коливань рівня протягом доби або після прийому їжі, а також тривалою стабільністю у пробах під час зберігання. Це пояснює, чому рівень СРБ є кращим діагностичним маркером запалення, ніж рівень ІЛ-6, прозапального цитокіну з коротшим часом напіврозпаду та чітко визначеними циркадними коливаннями. Було показано, що рівень ІЛ-6 $\epsilon$ нижчим вранці та вищим увечері. Ці зміни у концентрації ІЛ-6 можуть відображати пригнічення рівня цитокіна ендогенним кортизолом за механізмом зворотного зв'язку. 3 цих 
позицій, дослідження вмісту С-реактивного білка може розглядатись як перспективний метод розпізнавання дистрофічно-запальних уражень нирок. Беручи до уваги загальну біологічну функцію СРБ, слід вважати закономірним знаходження цього білка безпосередньо в "осередках ураження", тому ми досліджували даний протеїн і у сироватці крові і у сечі.

У контрольній групі практично здорових осіб середній рівень СРБ у сироватці крові і сечі

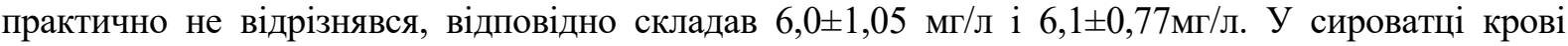
хворих на СНС при поступленні реєстрували підвищення рівня СРБ, практично у всіх хворих він досягав «гострозапального» діапазону і становив в середньому $15,64 \pm 3,56$ мг/л ( $<0,001)$. Одночасне визначення СРБ у сечі хворих на СНС виявило концентрації біомаркера, що в 4-5 разів перевищували показники в крові і становили в середньому $63,76 \pm 4,25 \mathrm{мг} /$ л $\left(\mathrm{p}_{1}<0,001\right)$. Проведений кореляційний аналіз між СРБ в сечі та вираженістю клінічних проявів обстежених пацієнтів показав наявність зворотної кореляційної залежності між вказаними показниками - r=-0,746 (p<0,05) (сильний зворотній кореляційний зв'язок). Нами було встановлено середньої сили прямий кореляційний зв'язок між рівнем СРБ в сечі і лейкоцитами в сечі, визначеними в аналізі сечі по Нечипоренку - $\mathrm{r}=0,546(\mathrm{p}<0,05)$, що підтверджує важливу роль СРБ як маркера активності запальної відповіді. Нами не виявлено достовірної залежності між рівнем СРБ і віком хворих та тривалістю захворювання. Проте, аналізуючи рівень СРБ у сечі в залежності від виявленого збудника, ми виявили прямий кореляційний зв'язок між рівнем СРБ і наявністю в сечі E. coli $(\mathrm{r}=0,476 ; \mathrm{p}<0,05)$. Тобто, чим вищим був СРБ у сечі, тим частіше в сечі визначається $\mathrm{E}$. coli. Завдяки проведеним дослідженням встановлено значне підвищення рівня СРБ в сечі при $\mathrm{CHC}$, яке у декілька разів перевищує рівень цього протеїна в крові, що може бути оцінено як ознака активних запальних реакцій в сечовому міхурі у відповідь на пошкодження патогенами. Ймовірно, синтезу СРБ у вогнищах ураження сприяє високий рівень прозапальних цитокінів.

Висновки. Ймовірно, синтезу СРБ у вогнищах ураження у сечовому міхурі та сечовидільних шляхах сприяє високий рівень прозапальних цитокінів, які вважаються індукторами його виділення.

Таким чином, однією із характеристик розвитку запального процесу у сечовому міхурі при СНС є наростання в сечі прозапальних цитокінів та рівня СРБ.

\section{ЛIТЕРАТУРА}

1. Бузолева Л. С. Характеристика штаммов бактерий, выделенных от больных с инфекциями мочевыводящих путей / Л. С. Бузолева, Н.А. Кузнецова // Тихоокеанский медицинский журнал. 2011. - №1. - C. 51-56.

2. Вельков В. В. С-реактивний білок в лабораторній діагностиці гострого запалення і оцінці ризику судинної патології / В. В. Вельков // Лабораторна діагностика. - 2007. - №4(42). - С. 53-68.

3. Глушко Л. В. С-реактивний білок: діагностичні та прогностичні перспективи визначення в плазмі / сироватці крові й інших біологічних рідинах організму / Л. В. Глушко, Н. М. Коваль, Н. М. Павелко // Клиническая иммунология. Алергология. Инфектология. - 2010. - №7. - С. 58-61.

4. Діагностична цінність С-реактивного білка в неонатальній практиці / Бондаренко М. П., Орловська І. Ю., Бондаренко М. Ю. та ін. // Здоровье ребенка. - 2010. - №2. - С. 23-31.

5. Лоран О.Б. Качество жизни у женщин после слинговой коррекции стрессового недержания мочи / Лоран О.Б., Серегин А.В., Давлатов 3.А. // Дальневосточный мед. журнал. - 2015. - №5. - С. 42-51.

6. Наносов Е. Л. С-реактивний белок - маркер воспаления при атеросклерозе / Е. Л. Наносов, Е. В. Панюков, Е. Н. Александрова // Кардиология. - 2003. - №7. - С. 53-62.

7. Нечипоренко А.Н. О клинических формах недержания мочи при напряжении у женщин с генитальным пролапсом / А. Н. Нечипоренко, А.С. Нечипоренко, А.В. Строцкий // Репродуктивное здоровье. Восточная Европа. - 2018. - Т. 8, №1. - С. 98-104.

8. Lapitan M.C., Cody J.D. Open retropubic colposushension for urinary incontinence on women // Cochrane Database Syst. Rev. - 2017. - Vol.7 - P. 29-32.

9. Abracham $\mathrm{N}$ The effect of time to release of an obstructing synthetic mid-urethral sling on repeat surgery for stress urinary incontinence / N. Abracham, L. Makovey, A. King // Neurourol. Urodyn. - 2017. - Vol. 36, № 2. - P. 349-353. 